\title{
Mechanism Towards Free, Fair and Credible Election in Africa: Challenges to Electorates and Other Actors of the Electoral Process
}

\author{
Muritala Dauda, Mohammad Zaki Ahmad, Mohammad Faisol Keling
}

\begin{abstract}
Election as a process of selecting those that will represent the interest of the masses need to be free, fair and credible. For an election to be credible, free and fair in which its result would be accepted by all, there is need for the actors/stakeholders of the electoral process to vigorously discharge their respective duties and obligation in the exercise. The electoral bodies, the civil society, the judiciary, political parties, the mass media, and even the masses who are the electorates are to be adequately orientated, cultured and given awareness on the beauty of participating in the selection process of their leaders. Despite the fact that, the voting behaviour of masses during an election tell more about the success of the system, but the actors or stakeholders involved in the electoral process can influence the level of voters' turnout in an election, by given the electorates regular orientation and awareness on the electoral system in the society. The study makes use of MoralityImplicit Theory to explain how the electoral process can be free and fair, if the actors involved in the process imbibed moral value and transparency in discharging their duties to the system without fear or favour. This study therefore is a qualitative in nature that employs the use of secondary source of data to explain the mechanism towards free, fair and credible election in Africa.
\end{abstract}

Index Terms:- Democracy, election, free and fair, electorates, Africa.

\section{INTRODUCTION}

Many scholars on African studies, particularly on democratic governance in the continent have different views on the future of democracy in the region. The reason for this is as a result of the manner in which elections are being handled which has arguably made it difficult to ascertain or describe an election to be free, fair or credible. As argued by Samuel P. Huntington in one of his works titled "the third wave", having studied the democratically changed of governments in Southern Europe, Latin American and Eastern Europe where there was significant improvement in the democratic transition in those places compare to the pace at which the transition is being handled in sub-Sahara Africa, he urged African leaders to take necessary caution in handling election matters in the zone [1].

Similarly, the case of "Arab Spring" of 2011 where countries like Libya and Egypt experienced dictatorship while countries such as Yemen, Syria and Iraq faced with

Revised Manuscript Received on July 10, 2019.

Muritala Dauda, School of International Studies, College of Law, Government and International Studies (COLGIS), Universiti Utara Malaysia (UUM).

Mohammad Zaki Ahmad, School of International Studies, College of Law, Government and International Studies (COLGIS), Universiti Utara Malaysia (UUM).

Mohammad Faisol Keling, School of International Studies, College of Law, Government and International Studies (COLGIS), Universiti Utara Malaysia (UUM). the challenges of radical sect called Islamic State in Iraq and Syria (ISIS), was also part of the setback facing the democratic progress in those affected areas [2]. In the same vein, the baneful effect of Boko Haram sect in countries like Nigeria, Cameroon, Chad and other West African countries relatively hindered some democratic progress which supposed to have been recorded in those countries [3]-[5].

Apart from the aforementioned challenges facing the democratic system in Africa, its leaders are also found of contributing to the hinderances that prevent rapid democratic transition through the abuse of state machinery for their favour [6]. This attitude is in no small measure, has arguably made it difficult for election observers to declare an election as free and fair. As argued by [6], there is no internationally approved guidelines or norms that stipulates how an election could be described as free and fair. However, despite the fact that no official or binding documents that could be pointed to as the approved international convention for free and fair election, there are some measures and conditions set for an election to be regarded as free, fair and credible [7]. These conditions include: right to participate (that is, right to vote and be voted for), freedom of association and expression, right of voter to cast the vote in secret, right for the winner to assume office, right for the loser to challenge the election result at the law court among others.

Aside from these rights, the electoral process needs to be strengthening more in order to yield a fruitful result. As argued by [8], there are many stakeholders involved in the electoral process. One of them is the Election Management Bodies (EMBs). For example, the EMBs in Nigeria comprised of both the Independent National Electoral Commission (INEC) and State Independent Electoral Commission. Same applicable to other countries, where the national electoral bodies would be in-charged of conducting general election at the national level, while the State electoral bodies on their own would be monitoring the conduct of local government elections and the likes. Other actors in the electoral process include: political parties and the candidates/contestants, the judiciary, the media, the security agencies, the accredited observes, the legislative assemblies and the electorates.

Among these actors in the electoral process, the electorates are the kingmakers that can decide by themselves on whom they prefer or choose to govern them. The voting power possess by the electorates is a tool which can be used 


\section{MECHANISM TOWARDS FREE, FAIR AND CREDIBLE ELECTION IN AFRICA: CHALLENGES TO ELECTORATES AND OTHER ACTORS OF THE ELECTORAL PROCESS}

in favour of candidates seeking for elective position either to the office of President, Governors, law makers at both the federal, state and local levels [8]. Hence, the unique role played by electorates and other stakeholders in the electoral process towards having free, fair and credible election cannot be overemphasized. It is against this backdrop that the study is examining the road towards having free, fair and credible election through the stakeholders of the electoral process in Africa.

\section{STATEMENT OF PROBLEMS}

There are numerous studies on elections and electoral process with particular reference to countries in Sub-Sahara Africa. These studies conducted have aroused different views on the manner and style at which Africa's democratic system, particularly the free, fair and credible election which is supposed to be the entering point for democratic system of government, is being handled. For instance, studies like [1], [2], [6], [8], [9]-[18] among others, have been carried out on elections and electoral processes in Africa. However, it was observed that despites their studies' recommendations, the problems of having reasonable free, fair and credible election is still persists in Africa. Thus, this study is viewing the actors or players involved in electoral process as the panacea towards having free and fair elections in Africa, only if they discharge their duties and roles diligently.

\section{METHODOLOGY}

A systematic review of literature is adopted by the study which focusing on elections, electoral processes and voting behaviours among the electorates in sub-Sahara Africa. This study is qualitative approach that premised its findings on the use of secondary data. This secondary data is sourced through published materials such as journal articles, books, Newspapers among others.

The study further makes use of Morality-Implicit Theory. According to the moral philosophers, there is relationship between moral notions and implicit theory of man and the society he lives [19]. The philosophers are also of the believe that implicit theory is central to man's moral beliefs [20]. For instance, Epstein "observed that individual extract moral values from their experiences within an implicit theory of reality, which contains a theory of the person and a theory of the world" [21]. The theory is explaining how morality translated to the behaviour of people which in turn guide their actions and reactions in the society. Peoples' orientation and perception to changes in the environment particularly in the society where they live reflect their moral-implicit theory response to the situation in their immediate environment. An example of this could be source in the Declaration of Independence of the Thirteen United States of America, 1776 that says:

We hold these truths to be self-evident, that all men are created equal, that they are endowed by their creator with certain unalienable Rights...That to secure these rights, Governments are instituted among Men...That whenever any form of Government becomes destructive of these ends, it is the Right of the People to alter or to abolish it, and to institute new Government [21].

Thus, the above illustration is trying to point out on the reasoning capacity of man to correct any abnormally or any act that has no moral justification or value, particularly in governance or any settings that has to do with coordination of human activities and material resources to benefit the society. Doing this would strengthening the governance and the betterment of the society.

Similarly, the Morality-Implicit theory is relevant to the study in the sense that if the actors or players involved in the electoral process discharge their duties and responsibilities diligently without fear or favour for the success of the system, such action perhaps, is capable of leading the electoral process to be factually considered as free, fair and credible. More importantly, the electorates who are the kings that play the most active role towards chosen their representatives could best be explained under the theory. This is because, the citizens who are the voters are rational, and the rationality could influence their voting on who would represent their interest or not [10]. Any government of the day that is interested in the continuity of his party to be at the helm of affairs, would always considered voters/electorates towards his activities, policies and government programmes which mostly have direct impact on the masses [8]. Although, all actors involved in the electoral process are very important, but the major participants of action in the election that would determine the winner or the loser are the electorates/the masses, this quality alone portrayed it as the king in the electoral process that should be reckoned with in order to have free, fair and credible election.

\section{CONCEPTUAL CLARIFICATION}

Election - this is a process of selecting candidates who would represent the interest of the masses at the helm of affairs.

Voting - this is an act of exercising one's civic responsibility by participating in the selection process of leaders in the society.

Voter turnout - this simply means the percentage or level/voting age that electoral official registered as voters, and who eventually came out to cast their vote in an election. Voters' turn out is essential in an election, because it determines the peoples' political participation [13]. Similarly, the active participation of voters or masses in the political system that determines who govern the society is most essential and it gives credibility to the electoral system and to the party/candidate who may eventually win the election. As it is paramount and fundamental rights of the citizens who have attained the prescribed voting age to exercise their civic right, masses should ensure that they turn-out en-masse to participate in the selection process of the leaders that would represent their interest.

Voting Behaviour - this implies the manner on how the electorates votes and the determinant of their vote. As argued in other study [22], the term voting behaviour is

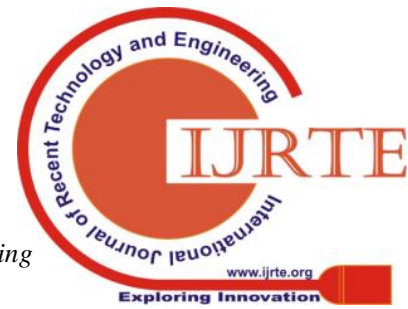


"important in those political systems in which the voter has some sort of choice, no matter how limited". Although, the voting behaviour of electorates is determined by some factors depending on how and where an electorate wish to belong.

Electoral Bodies - these are the bodies charged with the responsibility to screened and registered political parties and candidates, at the same time conduct free and fair election for winners to emerge.

Democratic Consolidation - the term was meant to imply the challenge of securing new democracies or making long the life expectancy of a democratic system. As argued by Mahmud that "democratic transitions and consolidation are interrelated in a continuum". The authoritarian government is removed through election which emerge a democratically elected leader(s) in a free and fair election. Therefore, the successful transition of government from one democratic government to another through free, fair and credible election could be described as a consolidation of democratic system of government [23], [24]. In a nutshell, the democratic consolidation could be simply termed as the transition of power from one democratically elected government/administration to another through the conduct of free and fair election.

\section{WHAT CONSTITUTE FREE, FAIR AND CREDIBLE ELECTION}

As earlier mentioned in the introductory part of this work that, there are players or stakeholders in the electoral process which comprised of Election Management Bodies, political parties and contestants, the judiciary, the media, the security agencies, the accredited observers, the legislative assemblies, and the electorates [8]. Each of these players has its own role to play towards having free, fair and credible election. For instance, the EMBs, are at the top ladder that is charged with the responsibility of organizing, supervising and conducting the electoral process. Similarly, the political parties produce the candidates that who contest as their flag bearers. The parties also responsible for the sponsoring or financing the candidate put forward. The media are to sensitize and educate the public or masses of the activities of other actors in the process.

Furthermore, the legislative assemblies are in charge of formulating the legal guide or framework that would serve as a procedure for the conduct of the election. While the judiciary is the arbiter who adjudicates over the election disputes. The security agencies which comprise of police and other civil security agencies are to ensure the election environment is secure and violence free from the stakeholders that would participate in the process. The accredited observers ensure that the all the contestants and the electoral bodies are conducting themselves in accordance with the rules and procedures governing the process.

In addition, the electorate as one of the players in the electoral process could be described as the main actor that influence actions which serves as the result of election. These are categories of people who are eligible to vote in an election. As argued by [8] that, "without the involvement of the electorate, there will be no voting, sorting, counting, collation, announcement of results and the declaration of winners". For instance in Nigeria, the Section 12 (1) of the country's Electoral Act 2010 stipulated that, "A person shall be qualified to be registered as a voter if such person:

a. Is a citizen of Nigeria,

b. Has attained the age of 18 years

c. Is ordinarily resident, works in, originates from the Local Government Area Council, or Ward, covered by the registration centre

d. Presents himself to the Registration Officer of the Commission for registration as a voter, and

e. Is not subject to any legal incapacity to vote under any law, rule or regulation in force in Nigeria [25].

The above reason is one the factors that disqualified some people not to qualified to vote in an election in Nigeria. Similarly, this applicable to other countries as what constitutes the eligible voters and candidate or parties in an election.

As argued by [10], there should be certain processes, procedures and actions that must have been done in order for an election to be free and fair. And these processes are tabulated and categorized as: before polling day, on polling day and after polling day.

Table 1: Procedures and Processes towards free and fair election [10]

\begin{tabular}{|c|c|c|}
\hline & Free & Fair \\
\hline $\begin{array}{c}\text { Before } \\
\text { Polling } \\
\text { Day }\end{array}$ & $\begin{array}{l}\text { - } \text { Freedom of speech } \\
\text { - } \text { Freedom of } \\
\text { assembly } \\
\text { - Freedom from fear } \\
\text { in connection with } \\
\text { the election } \\
\text { - Freedom } \\
\text { movement of } \\
\text { - Absence } \\
\text { impediments of to } \\
\text { standing for } \\
\text { election } \\
\text { - } \text { Equal } \\
\text { universal suffrage }\end{array}$ & $\begin{array}{l}\text { - A transparent electoral } \\
\text { process } \\
\text { - An election act and a } \\
\text { system for seat } \\
\text { allocation which grants } \\
\text { no special privileges to } \\
\text { any party, group, or } \\
\text { person } \\
\text { - An independent and } \\
\text { impartial electoral } \\
\text { commission. } \\
\text { - Impartial } \\
\text { education programmes } \\
\text { - Absence } \\
\text { impediments } \\
\text { inclusion in to } \\
\text { electoral register } \\
\text { - An orderly election } \\
\text { campaign } \\
\text { - Equal access to public } \\
\text { mass media } \\
\text { - No misuse of } \\
\text { government facilities } \\
\text { for campaign purposes }\end{array}$ \\
\hline
\end{tabular}




\begin{tabular}{|c|c|c|}
\hline $\begin{array}{c}\text { On } \\
\text { polling } \\
\text { day }\end{array}$ & $\begin{array}{l}\text { - Opportunity to } \\
\text { participate in } \\
\text { the election } \\
\text { - Absence of } \\
\text { intimidation of } \\
\text { voters }\end{array}$ & $\begin{array}{l}\text { - Secrecy of the ballot } \\
\text { - Adequate provisions to } \\
\text { ensure that voters only } \\
\text { vote once } \\
\text { - Well designed ballot } \\
\text { papers without serial } \\
\text { numbers } \\
\text { - Access to the polling } \\
\text { stations for accredited } \\
\text { party representatives } \\
\text { and election observers } \\
\text { - Impartial assistance to } \\
\text { incapacitated voters } \\
\text { - Proper treatment of } \\
\text { void ballot papers }\end{array}$ \\
\hline $\begin{array}{c}\text { After } \\
\text { polling } \\
\text { day }\end{array}$ & $\begin{array}{l}\text { - Legal } \\
\text { possibilities of } \\
\text { complaint } \\
\text { - Adequate } \\
\text { possibilities for } \\
\text { resolution of } \\
\text { election related } \\
\text { conflicts }\end{array}$ & $\begin{array}{l}\text { - Proper counting and } \\
\text { reporting procedures } \\
\text { - Proper precautionary } \\
\text { measures when } \\
\text { transporting election } \\
\text { material and securing } \\
\text { polling stations } \\
\text { - Impartial reports by the } \\
\text { media on election } \\
\text { results } \\
\text { - Impartial treatment of } \\
\text { election complaints } \\
\text { - Acceptance of the } \\
\text { election results by all } \\
\text { involved }\end{array}$ \\
\hline
\end{tabular}

The procedures indicated above in Table 1 if followed strictly without fear or favour by the concerned parties or players is capable of assessing or approaching a level playground for an election to be considered as free, fair and credible in African society.

\section{WHAT GIVES PEOPLE IMPRESSION THAT THEIR PARTY WON OR LOST AN ELECTION}

Mostly, after the conduct of an election the voters, candidates and their parties would be eager to hear the result of the election. To this effect, several studies such as [26][31] among others, have conducted on what constitute the existence of a winner or loser of an election. These studies revealed that voters themselves interpret winning or losing election. Winning in an election means being first. As argued by [31], some voters believed that winning an election is mostly all about having largest votes and seats in parliament and government. In some cases, voters who belong to a mini party may think that their party is winners if it was successful in some aspect. Whatever the case might be, the assumption of voters might be right or wrong depending on the final pronouncement from the electoral bodies headed by its chairman on the winner of an election. As part of ensuring free, fair and credible election, it becomes imperative for the electoral bodies to be neutral and transparency in the course of discharging its duties.

The electoral bodies, the voters, the judiciary, the media, accredited observers and other actors to the electoral process should be active in discharging their duties and functions in order to have a successful election where all parties would agree to the election's result. Making election credible and fair is capable of motivating many particularly, masses who are indifference to the election. In other word, such would increase peoples' participation in electoral system.

\section{POLITICAL PARTICIPATION OF VOTERS IN ELECTORAL SYSTEM: THE ROLE OF THE ACTORS \& RESULTS}

The involvement of masses in political activities such as election and its sorts, varies from one country to another. This is as a result of many reasons such as economic, religious, societal and environmental factors, personal reasons among others. These create avenue for political participation to be classified into groups namely: political gladiators (these are the contestants), political spectators (these comprised of voters and observers) and the Apathy (this category does not bother, care or motivate by the political activities in their societies). Therefore, for popular participation of masses in the political activities in Africa, all hands must be on deck. Meaning that, all the stakeholders involved in the electoral process have significant roles to play towards mass mobilization and awareness on the need for the public to partake in the selection or process of appointing leaders who will represent their interests during the decision making. The following are the roles expected to perform by the stakeholders of an electoral process so as to encourage people participation in the political activities:

Mass Media - as argued by [13] that "a free press is inevitable for democratic consolidation and citizen participation both during and after election". Media is avenue for public expression and it also a medium through which the political parties reached out to their supporters ${ }^{32}$. For that reason, media need to create awareness and orientation on the positive effect of public participation in the political activities.

Political Parties - it becomes part of the role of political parties to canvass and educate masses on the benefit of their participation in politics. Voting during an election is part of discharging one's civic responsibility, so all eligible voters are to be educated on the need to contribute to the process.

Civil Society Organisations - these groups are spread all over the world, in order to educate and awaken peoples' orientation and awareness for the masses to actively participate in promoting democratic value in Africa.

Electoral Managements Bodies (EMBs) - the bodies have major role to play toward improving the voting behaviour of the masses. Thus, the following roles are expected functions or roles to be performed by the EMBs:

a. The staff and other ad-hoc staff of the electoral bodies must be properly disciplined, trained and cultured on the conduct of their role and functions towards discharging their duties.

b. There is need for strong voters' registration system or platform in all the constituency. This will allow eligible citizens who attain the voting age to register 
their name and prepare for the exercise.

c. The voting style should be adjusted in order not to make the system boring to the voters. For instance, verification and voting could be done at same time in order to avoid distraction or boring of the voting to the voters.

d. The election materials should arrive promptly at the voting venue in order to avoid delay or lateness.

e. The use of electronic verification should be encouraged and the Electoral bodies should ensure that all machines are working properly before the election day.

f. The electoral bodies, the political parties and the civil society should ensure that the electorates/voters are well updated, orientated and sensitized on the democratic needs in the society.

g. There is need for maximum security within and around the voting centres from the commencement of the exercise. It should be noted that, the presence of security agents at the polling units or voting centres tension to the electorates rather than to ensure free and peaceful election.

h. The electoral bodies should promptly announce the election results after the collation from all voting centres.

i. While, the winner is announced by the electoral bodies, the loser should be allowed to challenge the election results if needs be, at the court of law.

\section{CONCLUSION}

The conduct of free, fair and credible elections could be attained in Africa if necessary precautions are taken from the concerned quarters. The electoral bodies, the mass media, judiciary, civil society, the masses/voters among others, are the drivers that can make an election to be free and acceptable by all in the society. Therefore, the success of an election is not the responsibility of only electoral bodies, but also the duties of all in the system. Having free and fair elections in Africa is arguably an assured way to democratic consolidation in the continent. This is also capable of achieving the desire result for Africa towards the realization of its goals and objectives for peace and rapid development in the continent.

\section{REFERENCES}

1. S. P. Huntington, The Third Wave: Democratization in the Late Twentieth Century. Norman: University of Oklahoma Press, 1993.

2. L. Diamond, "Facing up to the democratic recession," Journal of Democracy, 26(1), 2015, pp. 141-155.

3. A. O. Salaam, "Boko Haram: Beyond religious fanaticism," Journal of Policing, Intelligence and Counter Terrorism, 7(2), 2012, pp. 147-162.

4. F. Adegbulu, "Boko Haram: The emergence of a terrorist sect in Nigeria 2009-2013," African Identities, 11(3), 2013, pp. 260-273.

5. A. O. Adelaja, A. Labo, and E. Penar, "Public opinion on the root causes of terrorism and objectives of terrorists: A Boko Haram case study," Perspectives on Terrorism, 12(3), 2018, pp. 35-49. should be in a form that would not create fear or

6. G. Geisler, "Fair? What has fairness got to do with it? Vagaries of election observations and democratic standards," Journal of Modern African Studies, 31(4), 1993, pp. 613-637.

7. F. Fukuyama, "Why is democracy performing so poorly?" Journal of Democracy, 26(1), 2015, pp. 11-20.

8. J. Ojo, Nigerian electoral and credible elections. Available: https://punchng.com/nigerian-electorate-and-credibleelections/.

9. J. Elklit, and P. Svensson, "What makes elections free and fair?" Journal of Democracy, 8(3), 1997, pp. 32-46.

10. J. Elklit, "Electoral institutional change and democratization: You can lead a horse to water, but you can't make it drink," Democratization, 6(4), 1999, pp. 28-51.

11. S. Mozaffar, and A. Schedler, "The comparative study of electoral governance-Introduction," International Political Science Review, 23(1), 2002, pp. 5-27.

12. C. D. Miguel, A. A. Jamal, and M. Tessler, "Elections in the Arab world: Why do citizens turn out?" Comparative Political Studies, 48(11), 2015, pp. 1355-1388.

13. S. S. Mahmud, "The 2015 general elections: Voter turnout, voting behavior and democratic consolidation in Nigeria," Independent National Electoral Commission Conference Paper, 2015, pp. 1-17.

14. S. Shah, "Free and fair? Citizens' assessments of the 2013 general election in Kenya," Review of African Political Economy, 42(143), 2015, pp. 44-61.

15. H. Onapajo, "Nigeria's 2015 general elections: The salience of electoral reforms," The Round Table, 104(5), 2015, pp. 573-584.

16. R. Markowski, "The Polish parliamentary election of 2015: A free and fair election that results in unfair political consequences," West European Politics, 39(6), 2016, pp 1311-1322.

17. S. Birch, and C. V. Ham, "Getting away with foul play? The importance of formal and informal oversight institutions for electoral integrity," European Journal of Political Research, 56(3), 2017, pp. 487-511.

18. R. W. Frank, and F. M. I. Coma, "How election dynamics shape perceptions of electoral integrity," Electoral Studies, 48, 2017, pp. 153-165.

19. M. J. Sandel, Liberalism and its Critics. New York University Press, 1984.

20. E. Sampson, Justice and the Critique of Pure Psychology. Berlin: Springer Science and Business Media, 2012.

21. C. Y. Chiu, C. S. Dweck, J. Y. Tong, and J. H. Fu, "Implicit theories and conceptions of morality," Journal of Personality and Social Psychology, 73(5), 1997, pp. 923-940.

22. A. R. Ball, and B. G. Peters, Modern Politics and Government. NewYork: Palgrave Macmillan, 2005.

23. G. O'donnell, P. C. Schmitter, and C. J. Arnson, Transitions from Authoritarian Rule: Tentative Conclusions about Uncertain Democracies. Maryland: Johns Hopkins University Press, 2013.

24. M. Bratton, and N. V. de Walle, Democratic Experiments in Africa: Regime Transitions in Comparative Perspective. England: Cambridge University Press, 1997.

25. N. Emmanuel, Section 141 of the Electoral Act: A further bottleneck in the electioneering process. 2015, Available: https://poseidon01.ssrn.com/delivery.php?ID=587025086112 00700710803102910312610411307303703403109109509209 21130040810750061090670200070420400000150160720141 26067001064074037066031008013099123024119017082112 00505501406206908002012702706406411210109402612410 5073031104104083101008116001001082116116\&EXT=pdf.

26. C. Anderson, Loser's Consent Cep: c C. England: Oxford University Press, 2005.S. Singh, I. Lago, and A. Blais, "Winning and competitiveness as determinants of political and Engin

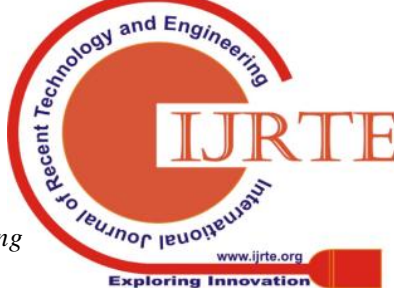


support,” Social Science Quarterly, 92(3), 2011, pp. 695-709.

27. B. Ferland, "A rational or a virtuous citizenry?-The asymmetric impact of biases in votes-seats translation on citizens' satisfaction with democracy," Electoral Studies, 40, 2015, pp. 394-408.

28. A. Blais, A. Morin-Chassé, and S. P. Singh, "Election outcomes, legislative representation, and satisfaction with democracy," Party Politics, 23(2), 2017, pp. 85-95.

29. D. Stiers, and R. Dassonneville, "Affect versus cognition: Wishful thinking on election day: An analysis using exit poll data from Belgium," International Journal of Forecasting, 34(2), 2018, pp. 199-215.

30. D. Stiers, J. F. Daoust, and A. Blais, "What makes people believe that their party won the election?" Electoral Studies, 55, 2018, pp. 21-29.

31. H. Coffé, "Citizens' media use and the accuracy of their perceptions of electoral integrity," International Political Science Review, 38(3), 2017, pp. 281-297. 